\title{
REWARD MANAGEMENT AND EMPLOYEE PERFORMANCE IN SELECTED LOCAL GOVERNMENTS IN ANAMBRA STATE, NIGERIA.
}

\author{
ONUORAH, A.N AND NWENE ANN NNEKA \\ Department of business administration \\ Faculty of management sciences, \\ Chukwuemeka odumegwu ojukwu \\ University, igbariam campu
}

\section{Abstract}

The study examined the effect of reward management as a tool for employee performance in the local government system of Anambra state. The problem of poor performance and neglects on Anambra state local government workers was the motivating factor for the research. The objectives of this study were basically to assess the effect of wages and salaries on employee performance, to determine the effects of recognition on employee performance and also investigate how staff training and development affect employee performance. The study was anchored on Adam's (1965) motivation theory of equity. As a cross-sectional survey research design, a structured instrument developed by the researcher to reflect such options as strongly agree, agree, undecided, disagree and strongly disagree popularly referred as five (5) points likert scale was used to obtain information from the respondents. The population of the study comprised of 3,085 employee of the selected local governments. A sample size of 592 employees was drawn from the population using Borg and gall's formular of (1973) of which 571 copies of questionnaires were duly completed and returned showing 96\% response rate. Research hypotheses were tested using Multiple Regression Analysis (MRA) which was carried out with the aid of Statistical Package for Social Science (SPSS) version 23. Findings from the study show that wages and salaries, staff recognition, training and development have significant impact on employee performance in the local government system. In view of the findings, the study recommended that government at all levels should provide the employee enough facilities to enables them enhance their motivation and job performance.

Keywords:Reward management, Employee performance, Local governments

\subsection{Introduction}

Every organization is created at one point in time to achieve a set up goals and objectives. To actualize this objective, a tactical motivational plan has to be formulated and implemented. This formulation of compensational plan is what is known as reward management. Thus, according to Armstrong and Murlis 2004), Reward management is concerned with the formulation and implementation of strategies and policies that aimed at compensating people fairly, equitably and consistently in accordance with their value to the organization.

As Milkorich Newman (2008) observed, management of reward systems ensures the creation and sustenance of competitive advantage for organizations. Thus, as earlier stated, objective of any organization is profitability. So organization's success depends on the employee's performance; poor performance is detrimental to the organization's success. Hence, the success of any organization is closely tied to the work performance of its employees. Reward 
management is very important to any business or organization because, it is seen as compensation given to the staff due to their efforts in the organization. This reward packages can come in form of bonus, pay raise (increase in salary/wages), public recognition, awards, good working environment, benefits etc.

Reward system refers to all the monetary and non-monetary payments that an organization provides for its employees in exchange for the work they perform. Hence two basic types of rewards includes extrinsic and intrinsic rewards. Extrinsic rewards (financial rewards) are concrete rewards that employee receives in exchange of the work performed such as salary and wages, pay raise, bonus, gratuity, over time pay and working conditions while intrinsic rewards relates to satisfaction that is derived from actually performing the job such as personal fulfillment and a sense of contributing something to society. Examples of nonfinancial rewards are genius appreciation, training and development, recognition, promotion, awards etc.

In drawing the linkage between reward and performance, Adams Stacey in his equity theory proposed that when workers are of the feeling that their input (knowledge, skills, attitudes and competencies) are coherent and consistent with their output (reward) both internally and externally, they will perform well on the job. The essence of effective reward management is to keep employees happy and healthy so as to achieve organizational goals and objectives, thus a happy and healthy employee is a plus to the organization. When employees are rewarded in the right manner, it is expected of them to give their best in terms of performance to the organization, this justifies an adage that says "To whom much is given, much is expected". All things being equal.

\subsection{Statement of the Problem}

Workers motivation for efficient performance in local Government system has not always received due attention in spite of the fact that they are the grass root and third tier of any Government. Hence, this study is born out of poor performance and neglects on Anambra State Local Government workers. This situation has remained a very serious problem. The employees are poorly motivated due to a combination of low morale and job dissatisfaction, poor incentives, meager salaries, inadequate controls and other behavioural sanctions (Kirunda 2004)

Several reforms has been done in the past to improve the morale and performance level of Civil Servants. Udoji Awards of 1974 done by General Yakubu Gowon is a typical example. Then other leaders including Former President Obasanjo also saw to the improvement in the pay of civil servants with the increase in minimum wage to N18,000 but the fact remains that the workers under this study are not receiving up to that amount. The recent agitation for new minimum wage of N30,000 which was later approved by President Muhammadu Buhari with effect from 18th April 2019 is yet to be implemented in the organisation under study. The Local Government financial autonomy which was set for a major boost by the Nigerian financial intelligence unit (NFIU) on 7th May 2019 is also yet to be implemented. All these and many other problems causes employee's low morale and job dissatisfaction as opined by Kirunda (2004).

The success and survival of any organization are determined by the way the workers are remunerated and rewarded (Lawler 2003). It must be noted that civil servants face a lot of challenges in the discharge of their duties in Nigeria (Ejumudo 2014). The reward system and motivating incentives will determine the employee's commitment and their attitude to work. The societal image of Local Government workers in terms of their purchasing power, social status etc has made the job unattractive thereby resulting into attrition. It is on this 
note, that the study examines the impact of reward management on the performance of civil servants in the Local Government of Anambra State, Nigeria.

\subsection{Objectives of the Study}

The general objective is to critically examine the effect of reward system in the performance of local government workers in Anambra State. The specific objectives of the study are:

1. To assess the effects of wages and salaries on employee performance.

2. To determine the effect of recognition on employee performance.

3. To investigate how staff training and development affect employee performance.

\subsection{Research Questions}

1. To what extent does wages and salaries affect performance of workers under study.

2. To what extent does recognition affect employee performance.

3. To what extent does staff training and development affect performance of workers.

\subsection{Research Hypotheses}

The following research questions were raised to guide the study objectives.

Ho: There is no significant effect of wages and salaries on employee performance.

Ho: Recognition does not have significant effect on employee performance.

Ho: Training and development does not affect employee performance significantly in the local Government System

\subsection{Significance of the Study}

This study that seeks to examine the relationship between reward and employee performance in the Local Government System of Anambra State, will be of great benefit to both Governments and Non-governmental organizations.

\subsection{Scope of the Study}

This research work deals with analysis of reward management and employee performance in selected Local Government civil service in Anambra State, Nigeria. Specific issues addressed in the study includes the use of financial reward (ie wages and salaries, incentives, commission, allowances, performance bonus etc and non-financial reward (ie recognition, promotion, award, training and development, gifts etc) and their impact on employees of Anambra State Local Government. The study covers four Local Government Areas each in the three senatorial zones of Anambra State, Nigeria.

\subsection{Limitations of the Study}

Except for inferential purpose, this research work should not be used as generalization of what is obtainable worldwide as the interest of the researcher has not included other organizations/Local Governments outside Anambra State but the Local Governments within Anambra State.

Some local government visited, found it difficult to release vital information needed for the study as approval had to come from above. Also there are challenges of inadequate completion, mutilation and outright loss of copies of the questionnaire by the respondents. In the same vein, experience from the field reveals that some of the questions posed to the respondents threw up more questions that need to be explored through future research.

Infact, the experience gathered in this researcher from the field was tasking as it was frustrating. However, regardless of the foregoing challenges, the study was able to triumph resulting in the successful completion of the work 


\subsection{REVIEW OF RELATED LITERETURE}

The study under this section is reviewed under the following sub-heading viz: Conceptual review, conceptual framework, theoretical exposition, theoretical framework, theoretical review and empirical review.

\subsection{Conceptual Review}

\subsubsection{Reward: Nature and characteristics.}

Efforts were made under this sub heading to define the following concepts - Reward (financial and non-financial), motivation, recognition, Local Government civil service and employee performance.

According to Armstrong (2001), reward systems consists of an organizations integrated policies processes and practices for rewarding its employee's in accordance with their contributions, skill and competence and their market worth.

Thompson (2002) defined reward as appreciation in cash or kind given to employees for their extra contributions to the organization. Armstrong (2009) opined that total rewards is a combination of financial and non-financial rewards in a given reward system. He further stresses that total reward has always been advocated for, because it is still not yet clear which of the rewards (financial or non-financial) is more effective in motivating employees for high performance.

Social recognition according to Rowley (2011) is the acknowledgement which an organization gives to the employee for accomplishment and that it satisfies an employee esteem need. Ryan (2013) also describes employee recognition in an organization as a nonfinancial reward that arouses inner feelings of satisfaction which gives him greater sense of belonging to the organization. Johnson (2007) noted that, recognition as a non-financial reward does not get eroded by mortgage, rent, utilities and other automatic payments from their bank accounts as it applies to the financial reward.

In a related development, motivation according to Kida Mahmud and Nuhu (2015) is an active form of a desire or need which must be satisfied. Then Onuora (2016) simply defined motivation as the driving force behind all people's action while employee motivation is a factor that causes an employee to pursue work tasks or goals. To Gupta (2006:446) it is stimulation of people to action to accomplish goals.

Furthermore Ugwu (2000) stated that Local Government Civil Service is a system of Government created for effective and efficient administration of localities. These Local Government workers are people employed by an established Local Government Service Commission to run the public service of localities. This Commission is empowered to regulate the affairs of all the employees in form of human resources management. In the same vein, Ogbuka (1993) opined that Local Government is an Institution of Government through which people manage local affairs under a law made for that reason by the Central Government

Ngige (2011) is of the view that, without adequate reward in an organization, current employees are likely to leave and replacement will be difficult to recruit. According to him, inadequate reward in the organization can cause strike action, increase grievances, and lead to forms of physical or psychological withdrawal ranging from absenteeism and turnover to increase visits to the dispensary and poor mental health. 
Reward system according to Obisi (2003) is a prize given to employees as an inducement towards their performance while Robert (2005) defines Reward system as the process of developing and implementing strategies, policies and systems which help the organization to achieve its objective by obtaining and keeping the people they need and increasing their motivation and commitment.

Fajana (2000) is of the opinion that the design and management of reward system constitute one of the most difficult human resources management (HRM) tasks for the general manager. This is so because, scarcely has any matter led to a strike action much more than wage and salary related issues. Therefore, it is appropriate to say that reward management is a matter that is closest to the heart of every employee and the employer (Banjoko, 2006).

\subsubsection{Employee Performance}

The concept of employee performance refers to all organizational outputs attributable to the employee (Ejimudo 2014). Similarly Bale and Holton (2009) construed employee performance as a record of all outcomes traceable to the employee in an organization. It is seen as the actions or the execution of tasks that were completed by individuals within a certain time (Swasto 2006).

Mbah, Mgbemena and Ejike (2015), employee performance is simply all behaviours of the employee towards organizational goals. Therefore, to motivate behaviour, the organization needs to provide an effective reward system. However in the context of this study, employee performance can be in form of creativity/innovation, job satisfaction, improved decision making capacity and goal attainment.

\subsection{Conceptual Framework}

The conceptual model below will guide our understanding of the subject throughout this research.

Fig 2.1.2 Relationship between reward system and employee performance

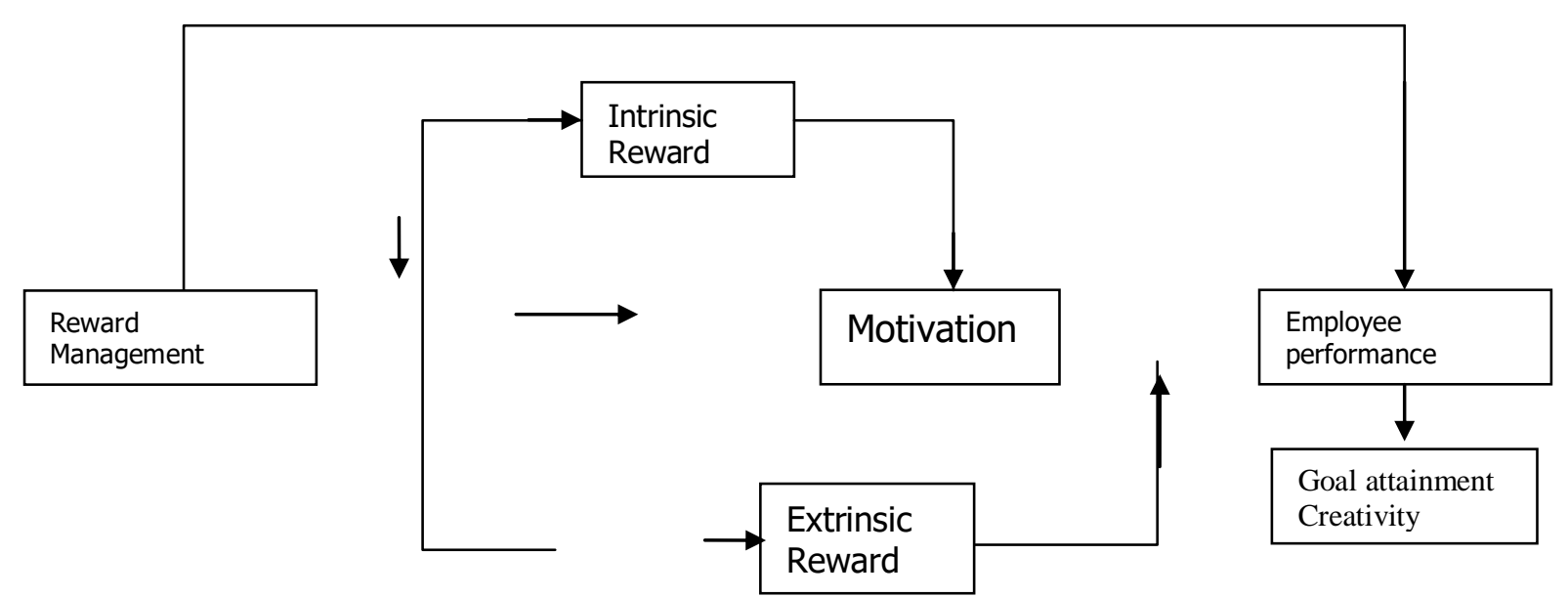

Source: Authors Conceptualization

The framework shows the two basic types of rewards viz: The intrinsic and extrinsic rewards which will equally serve as independent variables in this study while employee performance is the dependent variables. Looking at the diagram above, it is believed that the independent variable motivates or stimulates the morale of employees to put in their best in the workplace. Once an employee is rewarded, the next thing that follows suit is motivation. Hence, it is the 
motivation that propels an employee into action (performance). Therefore the glue that binds effective reward system and employee performance is motivation.

\subsection{Theoretical Framework}

This work is anchored on Adams (1965) Equity Theory of Motivation.

\subsubsection{Adams Equity Theory}

Equity theory developed by J. Stacy Adams states that once an individual has chosen an action that is expected to satisfy his needs, the individual assesses the equity or fairness of the outcome (reward). Equity theory was informed by the fact that employees seek to maintain equity between what they bring into the organization (inputs) and what the organization offers in return (reward) - Adams (1965). The most important thing to remember about equity theory is that, if rewards are to motivate employees, they must be perceived as being equitable and fair. Whenever people are not being fairly rewarded, they become dissatisfied and input is reduced.

Equity theory can be expressed in the form shown below.

Outcome of a person input of a person

$$
\begin{aligned}
& =\quad \text { Outcome of another } \\
& =\quad \text { input of another person }
\end{aligned}
$$

This theory believed that, there should be a balance of the outcome/input relationship for one person in comparison with another person because at any time individual feel inequity in outcome or whenever they are inadequately rewarded, they are bound to be dissatisfied which will eventually lead to reduction in the quantity of input and attrition in the organization.

\subsection{Empirical Review}

Many factors tends to affect employee performance in any organization thus working conditions, employer and employee relationship, training and development opportunities, job security and organization's overall policies and procedures rewarding employees and so on. Among all those factors mentioned above, motivation that comes with rewards is of utmost importance (Aktr et al, 2012). Thus, literature has identified reward as the route which organizations can employ to increase performance of employees (Al-Nsour 2012; Osibanjo, Abiodun and Fadugba 2012). In the same vein, pratheepkanth (2011) in his study of the relationship between reward and employee motivation found that a significant relationship exist between reward and employee motivation. On empirical studies among public secondary school teachers in Lagos State, Bello and Adebajo (2014) studied reward system and employee performance and arrive at findings that there is significant direct relationship between their performance and salary package.

Ghazanfar et al (2011) is of the motion that the human resource of any organization must be rewarded adequately for this will motivate them to achieve organizational goals and objectives. Similarly, Okwudili (2015) also carried out a study on effect on non-monetary reward on productivity of employees among a selected Government parastatals in Abia State and suggested for effective exploitation of human resource through implementation of nonmonetary rewards.

Armstrong (2009) in his study of Reward systems in human resource management argued that employees should be rewarded fairly and equitably than motivate them. 
Ejimudo (2004) also examined the relationship between reward system management and staff performance in Delta State Civil Service and concluded that the poor performance of the employees is as a result of poor and lack of adequate pay reward to them. Researchers like Ahmed and Ali (2008) in their literature "the impact of reward and recognition programs on employee motivation and satisfaction" founds that there is a positive relationship between rewards and work satisfaction as well as motivation. The impact of non-monetary rewards on employee performance Maryann (2013) argued that there is a significant relationship between employee performance and non-monetary rewards.

In another development, Ejike (2013) studied implication of employee recognition in an organization using a sample of 272 respondents drawn from selected firms in Anambra State. He found from the study that employee recognition as one of the non-financial rewards to the employee, has the capacity to influence the employee for high performance. In a similar vein, Kida, Mahmud and Nahu (2015) carried out a study on how financial and non-financial incentives can be used as tools for motivating employees of Libraries in tertiary institutions in Bornu State, Nigeria., the result found was that employees perform better when they are motivated or in anticipation of getting a reward either intrinsically or extrinsically.

Abu Abdissamad (2013) studied the effects of non-financial rewards in Nigeria public and private organization. His findings was that monetization policy of the government in public service had adversely affected the morale of public servants negatively as they felt that organizations official vehicle were purchased and maintained by them. The study also revealed that workers are dissatisfied since most of the fringe benefits that was source of motivation to them has all disappeared. Finally, researchers have attempted to compare monetary and non-monetary rewards in relation to employee performance. For instance, Ezigbo (2011) and Lotta (2012) argued that monetary and non-monetary rewards should be provided to the employees to increase their performance.

\section{RESEARCH METHODOLOGY}

In this segment, the study considers the methodology employed in this research. This segment describes the design of the study, sources of data, the population of the study, the sample size, research instrument, validity and reliability issues, and the method of data analysis.

\subsection{Research Design}

Cross sectional Survey research design was adopted carrying out the study. The nature of the study which involved interviewing a part of the defined population, informed the choice of design. Ikegwu (1997) opined that studies of this nature use survey method to look for information on facts, attitudes, practices and opinions of the respondents.

\subsection{Sources of data}

The data were obtained from two sources namely: primary and Secondary sources

\section{a. Primary Sources of data}

The primary data were generated from local government employees in Anambra State using a structured questionnaire.

\section{b. Secondary Sources of data}

Secondary data were collected from published sources (annual reports, handbook and pamphlets) of Local Government Service Commission, Awka Anambra State. Information from the internet, books, newspapers, journals/magazines, etc are of great help. 


\subsection{Population of the study}

The population of this study is the senior civil servants ranging from grade level 07 and above who work in the selected Local Governments in Anambra State. We presumed that, this category of workers can conveniently and accurately discuss issues relating to reward management and employee performance in their organization since Anambra State is comprised of three Senatorial Zones (Anambra Central, Anambra North and Anambra South). Therefore four (4) Local Governments was selected from each zone totaling 12 local Governments.

\subsubsection{The breakdown is as follows}

Population of selected Local Governments

\begin{tabular}{|l|l|l|}
\hline & Local Government & Number of employees \\
\hline S/N & Anambra central & \\
\hline 1 & Anaocha & 299 \\
\hline 2 & Awka North & 95 \\
\hline 3 & Awka South & 540 \\
\hline 4 & Njikoka & 266 \\
\hline & Sub total & $\mathbf{1 , 2 0 0}(\mathbf{1 3 7})$ \\
\hline & Anambra North & \\
\hline 5 & Ogbaru & 230 \\
\hline 6 & Onitsha North & 280 \\
\hline 7 & Onitsha South & 215 \\
\hline 8 & Oyi & 309 \\
\hline & Sub total & $\mathbf{1 , 0 3 4}(\mathbf{1 1 9})$ \\
\hline & Anambra South & \\
\hline 9 & Nnewi North & 88 \\
\hline 10 & Nnewi South & 300 \\
\hline 11 & Orumba North & 243 \\
\hline 12 & Orumba South & 220 \\
\hline & Sub total & $\mathbf{8 5 1}(\mathbf{9 8})$ \\
\hline & Grand total & $\mathbf{3 , 0 8 5}(\mathbf{3 5 4})$ \\
\hline
\end{tabular}

\section{Source: field survey, 2019}

\section{4: Determination of Sample Size.}

The sample size for this study was determined using the Borg \& Gall formular of (1973). Statistically, the Borg \& Gall (1973) formular for sample size is given by $\mathrm{n}=(\mathrm{Zx})^{2}(\mathrm{e})[\mathrm{N}]$

$(\mathrm{Zx})^{2}=$ Confidence level at 0.05

$\mathrm{e} \quad=$ Error of margin (0.05)

$\mathrm{N} \quad=$ Population of Interest $=3085$

$\mathrm{X}=$ Significance Level

\section{5: Sample Size and Sampling Technique}

Given the nature of this study, it was difficult to cover the entire population of (3085), so a fair representative sample of the population therefore was imperative. Accordingly, the sample size for the study was determined by using the Borg \& Gall (1973) formular for calculating sample size as follows

$\mathrm{n}=(1.960)^{2}(0.05)$ [3085]

$\mathrm{n}=(1.960)^{2}(0.05)$ [3085] 
$\mathrm{n}=(3.8461)(154)$

$=592.2994$

$\mathrm{n}=592$

To ensure good representation, the study adopted Bowley (1926) proportional allocation formular to distribute the sample into different strata for the basis of data collection. According to this formula, different strata of the population in a sample is accommodated. The Bowley (1926) proportional allocation formular is given as

$\mathrm{nh}=\mathrm{nNh}$ $\mathrm{N}$

Where $n h=$ number of units allocated to each stratum $\mathrm{n}=$ total sample size

$\mathrm{Nh}=$ number of items in each stratum in the population

$\mathrm{N}=$ total population

Proportion for Local Governments in Anambra central Senatorial Zone $\mathrm{nh}=\underline{1200 \times 592}$

$$
3,085=231
$$

Proportion for Local Governments in Anambra North Senatorial Zone

$\mathrm{Nh}=\underline{1034 \times 592}$

$$
3,085=198
$$

Proportion for Local Governments in Anambra South Senatorial Zone

$\mathrm{Nh}=\frac{851 \times 592}{3,085}=163$

The breakdown of a sample size and the number of questionnaires allocated to each of the Local Governments is shown in the table 3.51 below

Table 3.51

Breakdown Of Sample Drawn From Local Government Employees In Senatorial Zones Of Anambra State

\begin{tabular}{|l|l|l|}
\hline Senatorial Zones & Population & Sample \\
\hline Anambra Central & 1200 & 231 \\
\hline Anambra North & 1034 & 198 \\
\hline Anambra South & 851 & 163 \\
\hline Total & $\mathbf{3 0 8 5}$ & $\mathbf{5 9 2}$ \\
\hline
\end{tabular}

Source: field survey 2019

\begin{tabular}{|l|l|l|l|}
\hline Local Governments & Population & Sample & $\begin{array}{l}\text { Valid } \\
\text { Response }\end{array}$ \\
\hline L.Gs In Anambra Central & 1,200 & 231 & 227 \\
\hline L.G In Anambra North & 1,034 & 198 & 185 \\
\hline L.G in Anambra South & 851 & 163 & 159 \\
\hline Grand total & $\mathbf{3 , 0 8 5}$ & $\mathbf{3 5 4}$ & $\mathbf{5 7 1}$ \\
\hline
\end{tabular}

\subsubsection{Description of Research Instrument}

As earlier stated, the major instrument used in data collection for this study is the Likert scale (5 points) questionnaire (see Appendix). The Likert scale questionnaire (1999, pp 117-120) is 
a five-point scale in which the interval between each point on the scale is said to be equal. It is used to register the extent of agreement, or disagreement with a particular statement of an attitude, belief or judgment describing a situation or phenomenon. Questionnaire is a set of written questions that contains the instruments on an objective about which the respondent's written or verbal opinions are sought, Luck and Rubin (1987, pp 173-174). It measures the variables necessary to test the research hypothesis.

The Likert Scale is weighted thus:

- Strongly agree (SA)

- $\operatorname{Agree}(\mathrm{A})$

- Undecided (UD)

- Disagree (D)

- Strongly disagree
5 points

4 points

3 points

- 2 points

1 point

The mode of distribution was through personal delivery to ensure satisfactory and high return rate of questionnaires by respondents. The researcher and her research assistants distributed three hundred and fifty four (354) copies of questionnaires to respondents in the selected Local Government in Anambra State.

\subsection{Validity and reliability of the instrument}

This refers to the methods of determining the extent to which the instrument measures what it purports to measure. The validity of the instrument (questionnaire) used for this study was done through a discussion with the researcher's supervisor regarding the content format employed and its general suitability to the respondents as well as their appropriateness to the purpose of the research. Thus all the criticisms and corrections made in the questionnaire were reflected in the final draft. Regarding the reliability of the instrument, a method known as test re-test was used. It involved administering 20 copies of the instrument to civil servants outside the study area. After an interval of two weeks, the same instrument was administered to the same group of people and the responses (first and second) were analyzed through the application of spearman rank order correlation coefficient. The analysis returned coefficients of $0.80,0.83$ and 0.73 for the three research questions thus showing an average coefficient of 0.79

\subsection{Method of Data Analysis}

Statistics such as frequency tables and percentages were used in the analysis of personal characteristics while research hypotheses were tested using Multiple Regression Analysis (MRA). The research hypotheses were tested at 0.05 level of significance. Analysis was carried out with the aid of Statistical Package for Social Science (SPSS) version 23

\section{PRESENTAION AND ANALYSIS OF DATA}

This chapter presents the data obtained from the respondents through the administered questionnaires. Five hundred and ninety-two (592) were administered, among selected senatorial zone of Anambra state (Anambra Central, Anambra North, Anambra South). However, five hundred and seventy-one (571) questionnaires were retrieved. Therefore the analysis and interpretation of data were only based on the returned questionnaires. The validity and reliability of this study is highly ensured, despite the number of questionnaires not returned.. The method used was the Ordinary Least Square (OLS) regression technique. The method was adopted because it possesses unique estimating properties which include unbiased, efficiency and consistency when compared with other linear unbiased estimates.

Table 1: Summary of Respondents Demographics 
$(\mathrm{n}=571)$

\begin{tabular}{|l|l|l|}
\hline Characteristics & Frequencies & Percentage \\
\hline Gender & & \\
Male & 185 & 32.4 \\
Female & 386 & 67.6 \\
Total & 571 & 100 \\
\hline Status & & \\
Married & 490 & 85.8 \\
Single & 81 & 14.2 \\
Total & 571 & 100 \\
\hline Level of Education & & \\
WAEC/NECO & 68 & 11.9 \\
B.Sc/HND & 337 & 66.0 \\
MSc/MBA & 166 & 29.1 \\
PhD & - & - \\
Total & 571 & 100 \\
\hline Age & & \\
18-25 & 87 & 15.2 \\
26-33 & 137 & 23.9 \\
34-40 & 170 & 29.7 \\
41-50 & 160 & 28.0 \\
$51-$ above & 8 & 27.2 \\
Total & 571 & 100 \\
\hline Years in services & & \\
$0-10$ & 83 & 14.5 \\
11-15 & 188 & 32.9 \\
16-20 & 123 & 21.3 \\
21-above & 177 & 30.9 \\
Total & 571 & 100 \\
\hline Category of Employment & & 66.2 \\
GL 07-10 employees & 378 & 33.8 \\
GL 12-16 employees & 193 & \\
Total & 571 & \\
\hline Sorce: Fey Surey, 2019 & & \\
\hline
\end{tabular}

Source: Field Survey, 2019.

\subsection{Respondents' Demographic Variables}

Gender Distribution (SEX): The gender distribution constitutes a larger chunk in favour of male accounting for about $32.4 \%$, while female account for about $67.6 \%$

Status: majority of the respondents are married at the time of this study. $85.8 \%$ of them were married while $14.2 \%$ were single

Rank: Majority of the respondents representing about $11.9 \%$ were WAEC/NECO holders, followed by B.Sc/HND $66.0 \%$ while the least where M.Sc $29.1 \%$

Age of Respondents: Interestingly, the respondents were in the selected areas in their early twenties and late fifties from the selected institutions 
Years in service: This is to show the number of years one has been in his/her business $0-10$ years is $14.5 \%$, while $11-15$ yrs is $32.9 \%$, follow by $16-20$ yrs which is $21.3 \%$ finally 21 and above years is $30.9 \%$.

Category of Employment: majority of the respondentsrepresenting about $66.2 \%$ were under GL 07-10 employees, while GL 12-16 employees were 33.8

\subsection{Empirical Analysis}

The researcher employed ANOVA methods to explain the relationship between dependent and independent variables

Coefficients $^{\mathrm{a}}$

\begin{tabular}{|c|c|c|c|c|c|c|c|c|}
\hline \multirow{2}{*}{\multicolumn{2}{|c|}{ Model }} & \multicolumn{2}{|c|}{$\begin{array}{l}\text { Unstandardized } \\
\text { Coefficients }\end{array}$} & \multirow{2}{*}{\begin{tabular}{|c}
$\begin{array}{c}\text { Standardiz } \\
\text { ed } \\
\text { Coefficient } \\
\text { s }\end{array}$ \\
Beta
\end{tabular}} & \multirow[t]{2}{*}{$\mathrm{t}$} & \multirow[t]{2}{*}{ Sig. } & \multicolumn{2}{|c|}{$\begin{array}{l}95.0 \% \text { Confidence } \\
\text { Interval for B }\end{array}$} \\
\hline & & $B$ & Std. Error & & & & $\begin{array}{l}\text { Lower } \\
\text { Bound }\end{array}$ & $\begin{array}{l}\text { Upper } \\
\text { Bound }\end{array}$ \\
\hline \multirow{4}{*}{1} & $\begin{array}{l}\text { (Consta } \\
\text { nt) }\end{array}$ & $\begin{array}{r}276306.1 \\
91\end{array}$ & 9990.255 & & 2.9160 & .000 & 255903.367 & $\begin{array}{r}296709.01 \\
4\end{array}$ \\
\hline & W/S & 914.762 & 190.017 & 291 & 3.2999 & .000 & 526.695 & 1302.829 \\
\hline & REC & .774 & .069 & .704 & 2.6598 & .000 & .632 & .915 \\
\hline & STD & 1087.035 & 622.086 & .064 & 5.1555 & .001 & -183.434 & 2357.503 \\
\hline
\end{tabular}

a. Dependent Variable: EP

Model Summary ${ }^{\mathrm{b}}$

\begin{tabular}{|c|c|c|c|c|c|c|c|c|c|c|}
\hline \multirow{2}{*}{$\begin{array}{l}\text { Mode } \\
1\end{array}$} & \multirow[t]{2}{*}{$\bar{R}$} & \multirow{2}{*}{$\begin{array}{c}\mathrm{R} \\
\text { Squar } \\
\mathrm{e}\end{array}$} & \multirow{2}{*}{\begin{tabular}{|c|} 
Adjuste \\
$d R$ \\
Square
\end{tabular}} & \multirow{2}{*}{$\begin{array}{c}\text { Std. } \\
\text { Error of } \\
\text { the } \\
\text { Estimat } \\
\mathrm{e}\end{array}$} & \multicolumn{5}{|c|}{ Change Statistics } & \multirow{2}{*}{$\begin{array}{l}\text { Durbin- } \\
\text { Watson }\end{array}$} \\
\hline & & & & & $\begin{array}{c}\mathrm{R} \\
\text { Square } \\
\text { Change }\end{array}$ & $\begin{array}{c}\mathrm{F} \\
\text { Chan } \\
\text { ge }\end{array}$ & $\mathrm{df1}$ & df2 & $\begin{array}{c}\text { Sig. } F \\
\text { Change }\end{array}$ & \\
\hline 1 & .951 & .911 & .907 & $\begin{array}{r}38652.4 \\
2369\end{array}$ & .966 & $\begin{array}{r}244.0 \\
25\end{array}$ & 3 & 30 & .000 & 2.164 \\
\hline
\end{tabular}

a. Predictors: (Constant), W/S, REC, STD

b. Dependent Variable: EP

ANOVA $^{\mathrm{a}}$

\begin{tabular}{|r|r|r|r|c|c|}
\hline Model & Sum of Squares & df & Mean Square & F & Sig. \\
\hline Regre & 1274127320267 & 3 & 424709106755. & 244.027 & $.000^{\mathrm{b}}$ \\
Ssion & 617 & & 872 & & \\
Resid & 44820295724.44 & 30 & 1494009857.48 & & \\
ual & 4 & & 1 & & \\
Total & 1318947615992. & 33 & & & \\
\hline
\end{tabular}

a. Predictors: (Constant), W/S, REC, STD

b. Dependent Variable: EP

\subsection{Interpretation of the Result}


Coefficient of determination, This is also called the goodness of fit. This explains the percentages, proportion or total amount of variations in the regreesand or dependent variables as a result of changes in the regressors or independent variables included in the model. This will portray the usefulness significance of the regression. The closer its values is t0 1 the better the fit since it is usually $0-1$. From our regression result, $\mathrm{R}^{2}$ is $0.91 \%$. This implies that the independent variables can explain about $91 \%$ of the variable in the dependent variable, leaving the remaining $9 \%$ which would be accounted for by other variable outside the model. The adjusted $\mathrm{R}^{2}$ is $90 \%$ meaning that even with an adjustment in the independent variables, they can still account for about $90 \%$ of the changes in the dependent variables.

The F- statistics, this is used to test for the overall significant of the model. . From the result in table 4.3 above, our computed value of F- statistics is 244.0274 , while the probability is 0.000000 . Since the probability of the F- statistics in the computed output is less than the desired 0.05 level of significance, we accept and state that there is a significant relationship between the variable of the estimate and that of the dependent variable

The a' priori criteria which is determined by the existing business theories and indicates the signs and magnitude of the business parameter under review. in table 4.3 above, we find out that salary/wages has a positive sign given its value as 0.320163 , this implies that a unit increase in salary/wages increases the employee productivity by $32 \%$, this conform to our a' priori expectation. Recognition has a positive sign and its value is 0.562111 this implies that a unit increase in staff Recognition increases employee productivity by $56 \%$, this confirm to our theoretical expectation. Staff tanning and development has a positive sign and its value as 0.447117, this implies that a unit increases in Staff tanning and development increase the employee productivity by $44 \%$. This conforms to our a'priori expectation.

T- Statistics, this is carried out to know the significant of individual explanatory variables in the model. That is to find out the significant influence of explanatory variables on the dependent variables at chosen level of significant. It was discovered that salary and wages is statistically significant at 5\% level, (3.299902), this implies that it contributes significantly to employee productivity.

Staff Recognition is statistically significant at 5\% level of significant this implies it is one of the determining factor of employee productivity. Meanwhile, training and development is also statistically significant it is highest among all showing that it plays a significant role in employee productivity in Nigeria.

Test for autocorrelation, this is to test whether errors corresponding to difference observation are uncorrelated. It checks the randomness of the residuals. If the value of the durbin-watson from the regression result is close to 2 no autocorrelation in that regression result but if it deviates significantly then there is autocorrelation. The Durbin-Watson statistic (D.W) of 2 reveals no autocorrelation in the models. Hence, the result is good for econometric analysis.

\subsection{Hypothesis Testing}

Hypothesis One

The research in this study precisely in chapter one formulated a hypothesis and this have to be verified in order to find out the validity or otherwise of such proposition the research hypothesis is based on relevant statistics from the regression result. The hypothesis is tested on the basis of quantitative statistical analysis in this study

Ho: Salary and wages has no significant impact on employee performance in Anambra state local government system

Hi: Salary and wages has significant impact on employee performance in Anambra state local government system 
Drawing inference from our regression result in table 4.3, we found that the value of salary and wages is 3.299902 , while its probability is 0.0071 , this shows that salary and wages is statistically significant. Furthermore since its probability $(0.0071)$ is greater than $0.05 \%$ level of significance, we reject the null hypothesis ( $\mathrm{H} 0)$ and accept alternative hypothesis $(\mathrm{H} 1)$ which says that salary and wages has significant impact on employee performance Anambra state local government system

\section{Hypothesis Two}

Ho: Recognition has no significant impact on employee performance in Anambra state local government system

Hi: Recognition has significant impact on employee performance in Anambra state local government system

From table 4.3 above, we find out that computed value for Staffrecognition is 2.659861 while it's probability is 0.0251 this shown that the Staffrecognition is statistically significant at $5 \%$ level of significant. Based on this analysis we accept (Hi) and reject (Ho), which implies that Staffrecognition has significant impact on employee performance in Anambra state local government system

\section{Hypothesis Three}

Ho: Stafftraining and development has no significant impact on employee performance in Anambra state local government system

Hi: Stafftraining and development has significant impact on employee performance in Anambra state local government system

From table 4.3 above, we find out that computed value for stafftraining and development is 5.155515 while it's probability is 0.0000 this shown that the stafftraining development is statistically significant at 5\% level of significant. Based on this analysis we accept (Hi) and reject (Ho), which implies that stafftraining and development has significant impact on employee performance in Anambra state local government system.

\section{SUMMARY OF FINDINGS, CONCLUSION, AND RECOMMENDATIONS \\ 5.1 Summary of Findings}

Having conducted an empirical examination on the effect of reward benefit, the study has the following findings;

- Wages and salary has significant effect on employee performance in selected local governments in Anambra state.

- The study revealed that staff recognition has significant impact on employee performance of selected local governments in Anambra state.

- The study also shows that staff training and development has significant impact on employee performance on selected local governments in Anambra state.

\subsection{Conclusion}

The study attempted to use a regression to study the impact of reward in the performance of local government workers in Anambra State The result of the study shows that salary and wages, staff recognition and staff training have a positive impact on employee performance but such impact is strong and statistically significant. Their coefficients are statistically different from zero at less than 5 percent level of significance. It is obvious to management 
that salary and wages, staff recognition and staff training is a sine quo non for stimulating performance. When rewards are not given, workers tend to express their displeasure through poor performance and non-commitment to their job. It is therefore imperative for any organization to consider the needs and feelings of its employees and not just overlook them because "a happy worker they say is a productive worker". The study conclude that reward management has significant impact on employee performance in Nigeria

\subsection{Recommendation}

- Management must intensify the salary scheme of employees. It should be supported to upgrade their salary standard and pay as at when due.

- Management must be careful in the following factors to increase the employee motivation and performance through public recognition.

- Employees should be trained according to the present content of the environment. The reason is that training implies acquiring knowledge to fill the gap between what is known and what should be known.

\subsection{Contributions to Knowledge}

The major contribution to knowledge in this study is the contribution regarding reward management and performance of employees in organization from an often neglected research context like local government system in Nigeria with particular reference to Anambra state Local Government System. Thus, the findings of this study provides empirical evidence to existing literature from other states that good reward packages positively influences workers performance in the local government system.

\section{References}

1. Abu Abdissamad (2013) effects of non-financial rewards in Nigeria public \& private organizations

2. Adams, V. (1965). Pay and non-pay incentives, performance and motivation, prepared for WHO, December 2000, Global Health Workforce Strategy Group

3. Adebayo, J.P.(2004) "The Place of Hotel and Catering Industry in Tourism Development". New Nigeria. 11 (4) 67-87

4. Ahmed, M.S \& Ali R. (2008) Impact of reward \& recognition program on employee motivation \& satisfaction

5. Aktar S, Sachu M, Ali (2012) M. The impact of rewards on employee performance in commercial banks of Bangladesh: An empirical study. Journal of Business and Management 6(2):09-15.

6. Al-Nsour, M. (2012) Relationship between incentives and organizational performance for employees in the Jordanian universities "international journal of business and management" 7 (1), 78-89

7. Armstrong, M. and Murlis, H. A HAndbook of Salary Administration Koran Page,London. 1980

8. Armstrong M.A (2001) A handbook of human resources mgt practice ( $8^{\text {th }}$ ed)

9. Armstrong, M.A (2009) Handbook of HRM practice, London: kogan page

10. Bale R., \& Holton, M. S. (2009). "The impact of reward and recognition programs on employee's motivation and satisfaction: an empirical study." International Review of BusinessResearch Papers, 5 (4), 270-279

11. Banjoko J. (2006) Monetary incentives and vigilance. Journal of Experimental Psychology. 7 (7), 197-198. 
12. Ejike (2013) implications of employee recognition in an organization. International Journal of Finance, 3(4) 12-19

13. Esten, D. (2002), Linking rewards to commitment: an empirical Investigation of four UK call centre. International Journal of Human Resources management, 18 (12): 2095-2127.

14. Ezigbo \& Lotta (2012) Different between monetary \& non-monetary reward in relation to employee performance. International Journal of Management Sciences 4 (3) 23-34

15. Fayana J. (2000) Performance relatedpay: Objectives and applications. Human Resource Management Journal. 1992;2:16-33.

16. Flippo, E B.(1984), Personnel Management Mc-Graw-Hill, Tokyo.

17. Ghazaufar F; Chuanmin S., Khan M.M \& Bashir M. (2011) A study of relationship between satisfaction with compensation and work motivation "International Journal of Business and Social Science, 2(1), 120-131

18. Gupta, R.N (2006), Business organization and Mgt, New Delhi S. Chand and company Ltd

19. Helriegel, D, Solcum, J.W and woodman, R.W (1998) Organizational behaviour, southWestern college pub.

20. Ikeagwu, K.I (1997). Groundwork of Research Methods and Procedures. Institute of Development Studies, University of Nigeria, Enugu Campus.

21. Johnson, G.. (2007).Exploring Corporate Strategy, (7th Ed.) London: Prentice Hall

22. Kida M.I Mahmand Z.U. Nuhu, M.A (2015) Financial \& Non-financial incentives as tools for motivating employees of libraries in tertiary institutions in Borno state

23. Kirunda, H.K (2004), Performance based rewards and the performance of teachers in private secondary schools in kampala district, masters

24. Lawler EE. (2003) The effects of performance of job satisfaction. Industrial Relations.;7:20-28.

25. Lotta, L. (2013). The Impact of Financial and nonfinancial Rewards on Employee Performance in Federal Parastatals. Journals of Management, 3(4):29 - 38.

26. Maryann (2013) the impact of non-monetary reward on employee performance

27. Mba S.I, Mgbemena G.C \& Ejike D.C (2015) performance in civil service effective reward mgt \& employee

28. Mikovich, G.T. and Newnaan, J.M (2008) Compensation New Yoke: MC Graw-hill

29. Munford, R.C., and Gold, A.C., (2004), The Effect of Intrinsic and Extrinsic Rewards for Developers on Information Systems Project success, Project Management Journal, 37(4) 42-54.

30. Nelson, B. (2014). Misunderstanding rewards hampers motivation. Canadian HR reporter, Vol. 17. (10), 14-17

31. Ngige C.D (2011) Human Res. Mgt, Enugu, Holy ghost cathedral: social common

32. Ngige, C.D (2008) Management: An introduction Enugu: Saco Press

33. Obisi C. (2003) Personnel management. Ibadan: Jackbod enterprises

34. Ogbuka, J. (1993). "The recognition \& Reward of Employee Performance.” Journal of Labor Economics", 5 (4), 36-56.

35. Okwudili B.E (2015) Effects of non monetary reward on productivity of employees among selected Government parastatal Abia state Nigeria: Journal of business and management, 17(2):06-11

36. Onuora A.N (2016) Reward and compensation management,

37. Osibanjo E,Abiodun Z,Fadugba U, (2012), “The Impact of Rewards on Employee's Job Performance and Job Satisfaction," management and administrative science, (2), 5 ,431442. 
38. Pratheepkanth P. (2011) Reward system and its impact on employee motivation in commercial bank of Sri Lanka plc in Jaffna district. Global. Journal of Management and Business Research, 11(4). 85-92.

39. Robert (2005), Ines Meyer. The relative importance of different types of rewards for employee motivation and commitment in South Africa. Journal of Human Resource Management.;10(2):10.

40. Rowlay J. (2011) Motivation of staff in libraries library Mgt

41. Swasto, O (2006), The Influence of Intrinsic and Extrinsic Rewards on Employee Results: An Empirical Analysis in Turkish Manufacturing Industry. Business and Economic research Journal 3(3) pp.29-48.

42. Sule, C.J., (2018), The relative Importance of Intrinsic and Extrinsic rewards as Determinants of work Satisfaction, The Sociological Quarterly, 26, (3), 365-385.

43. Thompson, P. (2002) Total reward, London: IPd 2 -115P

44. Ugwu C.(2000)"Tourism in National Development" Tourism Today,PP. 42-45

45. Wether, S, \& Pavies, A, (1996). "The Impact of Person organization Fit on Job Satisfaction and Performance of the Employees," Procedia Economics and Finance, 11, (2014) $122-129$. 